\title{
Genetic variants associated with Crohn's disease
}

\author{
This article was published in the following Dove Press journal: \\ The Application of Clinical Genetics \\ 15 July 2013 \\ Number of times this article has been viewed
}

\section{Sonia Michail' \\ Gilberto Bultron' R William DePaolo² \\ 'The University of Southern California, Children's Hospital of Los Angeles, Los Angeles, CA, USA; ${ }^{2}$ Molecular Microbiology and Immunology, Keck School of Medicine, University of Southern California, Los Angeles, CA, USA}

Correspondence: Sonia Michail The University of Southern California, Children's Hospital of Los Angeles, 4650 Sunset Blvd, MS\#78,

Los Angeles, CA 90027, USA

$\mathrm{Tel}+\mathrm{I} 32336 \mid 5924$

Fax + I 323 36I 2425

Email sonia.michail@hotmail.com

\begin{abstract}
Crohn's disease is an immune-related disorder characterized by inflammation of the gastrointestinal mucosa, which can occur in any area throughout the digestive tract. This life-long disease commonly presents with abdominal pain, diarrhea, vomiting, and weight loss. While the exact etiology of this disease is largely unknown, it is thought to arise from an interaction between microbial, immunological, and environmental factors in a genetically susceptible host, whereby the immune system attacks the intestine as it cross reacts against gut microbial antigens. The study of genetic variants associated with Crohn's disease has shed light on our understanding of disease pathophysiology. A large number of genetic variants identified in Crohn's disease are related to genes targeting microbial recognition and bacterial wall sensing, the most common being NOD2/CARD15 gene. This review will discuss the recent advance in our knowledge of genetic variants of this disease and how they influence the disease course and prognosis.
\end{abstract}

Keywords: Crohn's disease, genetics, autophagy

\section{Introduction}

Inflammatory bowel disease (IBD) is defined as a group of chronic intestinal conditions characterized by inflammation in the intestine. The most common types of IBD are Crohn's disease (CD) and ulcerative colitis (UC). CD can occur in any area along the alimentary tract, but UC is localized primarily to the large intestine. Full thickness of the bowel wall is often affected in $\mathrm{CD}$, while only the mucosa is involved in UC. IBD is a common disorder worldwide, with a prevalence of $0.1 \%-0.4 \%$ of the general population. ${ }^{1}$ In the United States, the Center for Disease Control estimates that over 1.4 million Americans are affected by this disease, with an overall estimated annual health care cost exceeding US\$1.7 billion (cdc.gov/ibd/). IBD is currently without a cure, requires life-long care, interferes with quality of life, and frequently necessitates surgical intervention. Therefore, it has been recognized as one of the top five gastrointestinal disease burdens in the USA. Recent international trends suggest that there is an increase in the incidence of $\mathrm{CD}^{2}$ Whether this finding represents a true rise in the incidence of the disease or merely reflects an improvement in diagnostic and reporting methods is difficult to determine at the present time. The past few decades have heralded new discoveries in IBD, most of which are related to the genetics of the disease, diagnostic tools, and management strategies. Recent discoveries have brought much attention to the genetic predisposition of patients with IBD. Those genetic variations are largely related to the innate immune system and microbial recognition. ${ }^{3-7}$ 


\section{Genetic variants in Crohn's disease}

$\mathrm{CD}$ is a complex, multifactorial disease with strong genetic associations that lead to aberrant, chronic mucosal inflammation after exposure to environmental or microbial triggers. Thus far, 163 risk loci have been identified in patients with $\mathrm{IBD},{ }^{8}$ many of which are involved in innate immune responses and mucosal homeostasis. Currently, our genetic knowledge of $\mathrm{CD}$ is applied to understanding the natural history of the disease, describing racial predominance, predicting early onset stricturing and fistulizing, and determining location and overall severity of disease. Wagner et al recently described an association between mutations in toll-like receptor (TLR) 4 (rs4986790) and interleukin 10 receptor, alpha subunit (rs22291130) with Mycobacterium avium subspecies paratuberculosis positive CD patients, ${ }^{9}$ further implicating the role of microbial triggers and aberrant genetic responses in the immune system. This genetic data is helpful information that will possibly lead to the ultimate discovery of etiologies for the disease.

Significant CD risk has been associated with NOD2/ CARD 15, ${ }^{10}$ IBD5, and DLG5; ${ }^{11}$ IL23R and ATG16L $1^{4}$ have also been identified as CD susceptibility genes (see Table 1 for gene expansions). Genetic variants of Immunity-related GTPase family M (IRGM) have been significantly associated with $\mathrm{CD},{ }^{5}$ and it will be discussed later in this review, along with the other variant in the autophagy pathway, ATG16L1.

Three single nucleotide polymorphisms (SNPs) found within the NOD2/CARD15 gene (R702W, G908R, and 1007 fsinsC) were found to be racially distinct. These SNPs have been established as independent risk factors for $\mathrm{CD}$ in Caucasians. ${ }^{10,12-14}$ Biank et al reviewed ten manuscripts, which together included 1319 children with NOD2/CARD15 mutations. ${ }^{15}$ They concluded that Caucasian children with European ancestry have similar attributable risks for developing $\mathrm{CD}$ as adults due to NOD2/CARD15. Furthermore, as stated previously, and currently restated by Biank et al, ${ }^{15}$ the NOD2/ CARD1 5 mutational variants are nearly absent or rare in East Asians, Arabs, Africans, and African-Americans. ${ }^{16-20}$

Genome wide association studies (GWAS) have been used very effectively in IBD genetic research. Deep resequencing of GWAS data has identified highly significant variants at CARD9, NOD2/CARD15, CUL2, and IL18RAP, which contribute to risk associations of previously defined variants at these loci, and as well, showed the functionality of the newly implicated NOD2/CARD15 variants. Rivas et al went on to describe additional protective variants at IL23R, ${ }^{21}$ and Stoll et $\mathrm{al}^{22}$ showed DLG5 R30Q is a modest risk gene for $\mathrm{CD}$.
Further analysis of the data by Stoll et al revealed gender differences in allele frequency of R30Q between adult male CD cases and controls. ${ }^{22}$ They concluded that the DLG5 R30Q variant confers increased risk to adult males for $C D$. Biank et a ${ }^{15}$ compared the results of their pediatric CD study sample to the adult CD study sample results reported by Friedrichs et $\mathrm{a}^{23}$ and found the allele frequency of R30Q in children with $\mathrm{CD}$ to be $10.7 \%$ for males and $5.6 \%$ for females. The allele frequency of R30Q for controls was $8.3 \%$ for males and $12.3 \%$ for females. This difference of allele frequencies among females with $\mathrm{CD}$ and controls shows that R30Q may have a protective effect in female children. ${ }^{15}$

Innate cytokines produced by antigen presenting cells in response to microbial stimulation are critical for the induction of specific $\mathrm{T}$ effector responses that can combat invading bacteria or viruses. Interleukin (IL)-12 is an innate cytokine composed of a 40 and a p35 subunits, which are essential for the polarization of interferon- $\gamma$-producing $T$ helper $1\left(T_{H} 1\right)$ cells. Interestingly, a second innate cytokine called IL-23 was discovered in $2000,{ }^{24}$ and it shares the p40 subunit of IL-12, but instead of $\mathrm{p} 35$, it heterodimerizes with a unique p19 chain. Early studies examining IL- 12 deletion of the 40 chain or via neutralization by antibodies targeting the $\mathrm{p} 40$ chain may have also effected IL-23-mediated responses. ${ }^{25,26}$ However, over the last 12 years IL-23 has emerged as a proinflammatory driver in gastrointestinal inflammation. IL-12 is important for $\mathrm{T}_{\mathrm{H}} 1$ and interferon- $\gamma$ responses, whereas IL- 23 has been shown to expand IL-17 producing $\mathrm{T}_{\mathrm{H}} 17$ cells $^{27}$ and IL-17-producing innate lymphoid cells ${ }^{28}$ via expression of IL-23R..$^{28,29}$

The IL-23/IL-17 inflammatory axis has now been implicated in the pathogenesis of Crohn's disease. ${ }^{30-32}$ This conclusion comes in part from the findings that $\mathrm{CD}$ patients have a higher number of circulating IL-17+ cells $\mathrm{s}^{33}$ and from a study by Rismo et al, ${ }^{34}$ which showed that increased messenger (m) RNA expression of tumor necrosis factor (TNF) and IL17A in healed mucosa significantly increased the risk of relapse (hazard ratio $[\mathrm{HR}]=3.4, P=0.03$, sensitivity $80 \%$, specificity $38 \%$ and $\mathrm{HR}=4.1, P=0.008$, sensitivity $81 \%$, specificity $61 \%$, respectively).

More thorough investigations linking genetic variants of IL23, IL17, NOD2/CARD15, IRGM, ATG16L1, and DLG5 to mRNA expression, protein expression, gender, age, race, and phenotypic outcomes will help us to further understand the etiologies of Crohn's disease. A comprehensive list of the main genetic variants in $\mathrm{CD}$ is summarized in Table 1. In summary, the mutational variants in $\mathrm{CD}$ further describe a defect in bacterial sensing, as mentioned by Wagner et $\mathrm{al}^{9}{ }^{9}$ and an exaggerated response of the intestinal immune system. 
Table I Most clinically relevant and GWAS replicated CD genes

\begin{tabular}{|c|c|c|c|}
\hline GENE & SNP or mutational variant & Function & Phenotype/comments \\
\hline NOD2/CARDI 5 & I007fs, G908R, R702W $\mathrm{W}^{86,87}$ & Innate immune responses & Ileal disease. Stricturing phenotype. \\
\hline TLR4 & Asp299Gly 88 & Lymphocyte lineage & \\
\hline IL23R & RSI0048I96,89 & & Variants lead to increased risk or protection for $C D$ \\
\hline OCTNI & $\mathrm{rs} 1050152^{3}$ & & Fistulizing disease in NOD2/CARDI5- patients \\
\hline ATG I6LI & $\mathrm{T} 300 \mathrm{~A}^{3,4,90}$ & $\begin{array}{l}\text { Mucosal homeostasis and cellular } \\
\text { component degradation }\end{array}$ & Autophagy pathway \\
\hline IRGM & RSII74I86| $\left.\right|^{8,91}$ & & Regulation of autophagy formation in response to \\
\hline DLG5 & $\mathrm{R}_{30} \mathrm{Q}^{22}$ & & intracellular pathogens \\
\hline LRRk2 & RSIII $175593^{65}$ & & $\begin{array}{l}\text { Common in pediatric CD; Inversely related in } \\
\text { female children }\end{array}$ \\
\hline IBD5 & $503 F^{92-94}$ & & $\begin{array}{l}\text { The } 503 \mathrm{~F} \text { variant ( } \mathrm{rs} \mid 050152) \text { of OCTNI, is near } \\
\text { the center of the IBD5 haplotype }\end{array}$ \\
\hline PTPN22 & Rs247660 I 95,96 & $\begin{array}{l}\text { Responsiveness of } \mathrm{T} \text { and } \\
\mathrm{B} \text { cell receptors }\end{array}$ & $\begin{array}{l}620 \mathrm{~W} \text { gain-of-function variant is associated with } \\
\text { reduced risk of } C D\end{array}$ \\
\hline IL IOR & $1082 \mathrm{~A} / \mathrm{G}^{97}$ & $\begin{array}{l}\text { T regulatory cell responses } \\
\text { and anti-inflammation }\end{array}$ & Increased risk of CD \\
\hline TNF alpha & $308 A^{98}$ & Extra-intestinal associations & Uveitis risk \\
\hline
\end{tabular}

Notes: Bolded genes are highly significant genes in multiple GWAS. Nucleotide-binding oligomerization domain-containing protein 2 (NOD2) also known as caspase recruitment domain-containing protein I5 (CARDI5) or inflammatory bowel disease protein I (IBDI) is a protein that in humans is encoded by the NOD2 gene, which plays an important role in recognizing bacterial molecules and stimulating an immune reaction. ${ }^{99}$ NOD2 is an intracellular pattern recognition receptor, which recognizes molecules containing the specific structure called muramyl dipeptide found in bacteria. ${ }^{100}$ TLR 4 is a toll-like receptor. It detects lipopolysaccharide from gram-negative bacteria and is thus important in the activation of the innate immune system. ${ }^{101}$ Interleukin 23 receptor (IL23R), is a type I cytokine receptor. ${ }^{102}$ OCTNI encoded protein is an integral protein of the plasma membrane responsible for the cotransport of sodium ions and ergothioneine, which is an antioxidant, into cells. ${ }^{103}$ Autophagy-related protein $16-I$ (ATGI6LI), is a protein that is essential for autophagy. ${ }^{104}$ Immunity-related GTPase family M protein (IRGM), which plays a role in the innate immune response by regulating autophagy formation in response to intracellular pathogens. ${ }^{105}$ Disks large homolog 5 (DLG5), which functions as a scaffolding molecule at sites of cell-cell contact. ${ }^{106}$ The protein encoded by this gene localizes to the plasma membrane and cytoplasm and interacts with components of adherens junctions and the cytoskeleton. It is proposed to function in the transmission of extracellular signals to the cytoskeleton and in the maintenance of epithelial cell structure. Leucine-rich repeat kinase 2 (LRRk2), encodes a protein which is a substrate for chaperone-mediated autophagy. ${ }^{107}$ The RSI I 175593 SNP for LRRK2 just downstream MUC I 9 encodes for protective mucus on epithelium. IBD5 is a $250 \mathrm{~kb}$ cytokine gene cluster on chromosome $5 \mathrm{q} 3 \mathrm{I}$ and associated with risk of developing Crohn's disease. ${ }^{92}$ Protein tyrosine phosphatase, non-receptor type 22 (PTPN22) affects the responsiveness of T and B cell receptors, and mutations are associated with autoimmune diseases. ${ }^{108}$ Interleukin I0 receptor (ILIOR), the protein encoded by this gene is a receptor for interleukin 10, which has been shown to mediate the immunosuppressive signal of interleukin 10 , and thus inhibits the synthesis of proinflammatory cytokines. ${ }^{109}$ Tumor necrosis factor-alpha (TNF-alpha) is a cytokine involved in systemic inflammation. ${ }^{110}$

Abbreviations: CD, Crohn's disease; GWAS, genome-wide association studies; SNP, single nucleotide polymorphism; TLR, toll-like receptor; OCTNI, organic cation transporter novel type I; GTP,guanosine triphosphate; MUC, mucin gene; IBD5, inflammatory bowel disease 5.

\section{Autophagy in Crohn's disease}

Autophagy is a conserved cellular pathway that maintains cellular homeostasis via the degradation of cytosolic contents and proteins..$^{35}$ This process occurs via the sequestration of cytoplasmic contents into autophagosomes and the subsequent fusion with lysosomes for degradation and recycling (Figure 1). ${ }^{36,37}$ Autophagy has drawn interest beyond the extent of homeostatic regulation and is now a widely recognized pathophysiological process in autoimmune diseases, ${ }^{38-46}$ cancer, ${ }^{47,48}$ and IBD. ${ }^{3,49,50}$

Intestinal tissues are in close proximity to the microbial world and therefore rely on intracellular defense mechanisms like autophagy in order to prevent aberrant or harmful inflammation. Thus, defects in directing commensals and pathogens to the autophagy pathway may impair bacterial responses and promote an environment in which anticommensal immunity and inflammation is favored.

ATG16L1 gene variant rs2241880 (T300A) is a nonsynonomous coding SNP that results in a single amino acid change in the mature protein. rs2241880 was identified in both a transmission disequilibrium test and a case controlled comparison in a study by Hampe et $\mathrm{al}^{4}$ examining CD patients in a German cohort. These data suggest that the $\mathrm{CD}$ risk conferred by ATG16L1 gene variation is confined to individuals carrying allele $\mathrm{G}$, with a $60 \%$ frequency of the $\mathrm{G}$ allele in affected individuals compared to $53 \%$ in controls. These data were confirmed in patients from the United Kingdom ( $\mathrm{G}$ allele frequency was $59 \%$ affected versus $52 \%$ in controls). ${ }^{4}$ Interestingly, a statistical interaction between rs2241880 and the CARD15 genotypes was discovered. ${ }^{4}$ This genetic association is further supported by the findings that muramyl dipeptide enhances autophagy and is inhibited by ATG16L1CD risk allele. ${ }^{51,52}$ Additionally, the ATG16L1 (T300A) variant has been associated with elevated IL-1 $\beta$ mRNA levels independently of inflammasome activation but not TLR ligands. ${ }^{53}$ These data suggest that defects in autophagy lead to increased IL-1 $\beta$ secretion and inflammation downstream of NOD2/CARD15.

In addition to activation via pathogen recognition receptors, ${ }^{52,54,55}$ type 1 and type II interferons are potent inducers 


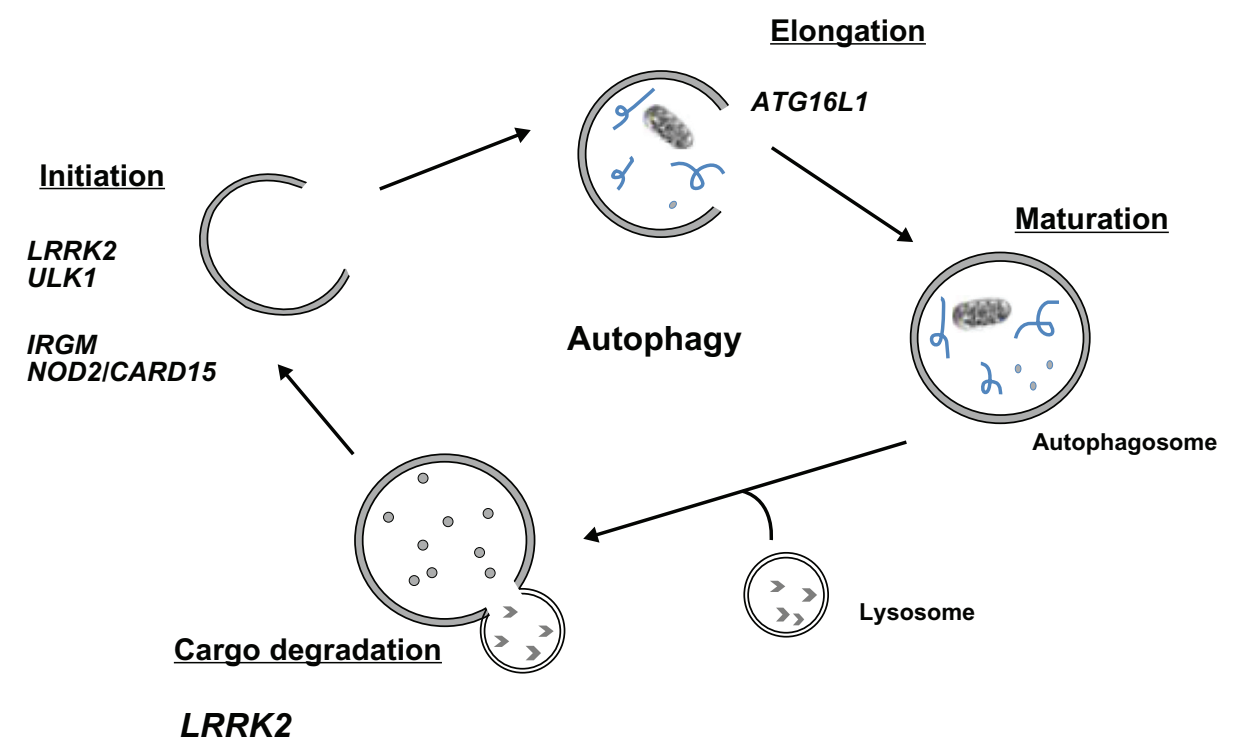

Figure I Genes of the autophagy pathway implicated in Crohn's disease susceptibility.

Notes: There are several phases in the autophagic pathway. Initiation is the formation of the preautophagolysosome, elongation, maturation, followed by fusion of the lysosome and degradation of the cargo.

Abbreviations: LRRK2, leucine-rich repeat kinase 2; IRGM, immunity-related GTPase family M protein; NOD2, nucleotide-binding oligomerization domain-containing protein 2; CARD I5, caspase recruitment domain-containing protein I5; ATGI6LI, autophagy-related protein I6-I; GTP, guanosine triphosphate; ULKI, serine/threonine kinase.

of the autophagy pathway. ${ }^{56-58}$ Interferon- $\gamma$ can induce the expression of immunity-related guanosine triphosphate (IRG) proteins in mice while human IRG lack interferon response elements. IRGM is the most well-known member of the IRG family and is constitutively expressed at high levels in human cells. ${ }^{56}$ Similar to ATG16L1, genetic variants of IRGM have been significantly associated with $\mathrm{CD}$ risk; ${ }^{5,59}$ however, unlike ATG16L1, studies have been unable to correlate NOD2/ CARD15 variants with IRGM. ${ }^{60,61}$

Interestingly the lead SNP in IRGM (rs13361189) identified in $\mathrm{CD}$ is in perfect linkage disequilibrium with a $20 \mathrm{~kb}$ deletion upstream to the IRGM locus, ${ }^{59}$ hence the risk haplotype includes both deletion and SNP. Brest et $\mathrm{al}^{62}$ demonstrated that rs13361189 and the deletion are in perfect linkage disequilibrium with a synonymous exonic SNP (rs10065172) that alters IRGM levels and the binding of microRNA196. ${ }^{62}$ IRGM knockdown and microRNA196 overexpression prevents the targeting of adherent invasive $E$. coli to the autophagosome, ${ }^{62}$ suggesting that aberrant immune activity or loss of tolerance to commensal may explain the role of IRGM rs13361189 in CD.

While ATG16L1 is the most widely examined and wellcharacterized variant of the autophagy pathway associated with $\mathrm{CD}$, recent studies have identified other important genes. Leucine-rich repeat kinase 2 (LRRK2) is a member of the leucine-rich repeat kinase family. ${ }^{63}$ Three studies have identified variants in LRRK2 associated with CD. ${ }^{64-66}$ The SNP, rs 11175593, is located in a noncoding region on chromosome 12 . Interestingly, reports have shown that LRRK2 may be a factor in autophagy via a scaffolding role during protein-protein interaction. ${ }^{67-69}$ ULK1 is a serine/ threonine-protein kinase, which forms a complex with Atg1 and activates the Atg1/ULK1 complex via dephosphorylation of Atg1. This is the most upstream step of autophagosome formation. ${ }^{70}$ The SNP in ULK1 (rs12303764) was identified by Henckaerts et $\mathrm{al}^{71}$ in a population study of $1282 \mathrm{CD}$ patients of Western European origin. NOD2/CARD15 variants were shown to have no impact on the association of rs 12303764 with CD. ${ }^{71}$ The identification of SNPs in LRRK2 and ULK1, and the already described role of ATG16L1, further establish the regulation of autophagy as an important cellular function in CD. However, more in-depth analysis of both LRRK2 and ULK1 SNPs must be performed to fully understand the functional consequence in $\mathrm{CD}$ pathogenesis.

\section{Genetic predictors of Crohn's disease clinical outcome}

Since genetic factors do not change over time, the identification of genetic variants that may predict disease behavior and prognosis are superior to other predictive factors such as serological and clinical parameters. Despite the evergrowing number of susceptibility loci in $\mathrm{CD}$, there are only a few variants associated with statistically significant clinical outcome and prognosis. ${ }^{72}$ In addition to its identification as a susceptibility locus, NOD2/D15 has also been identified in studies examining outcomes of CD. The presence of NOD2/ 
CARD15 has been associated with a more aggressive clinical course involving higher risk of intestinal strictures, earlier need for surgical intervention, and less postoperative diseasefree intervals. ${ }^{13,73,74}$ NOD2/CARD15 was also found to be the most important factor for ileal location and stenosing and penetrating disease. ${ }^{72}$

The presence of a genetic variant in Janus kinase 2 (JAK2) as a predictor for ileal involvement and stenosing disease was found in a cohort of 1528 European CD patients. ${ }^{72}$ Interestingly Prager et $\mathrm{al}^{15}$ demonstrated that patients with the C risk allele within JAK2 rs 10758669 have increased epithelial permeability, suggesting that the effect on disease behavior may be due to alterations in overall intestinal permeability.

Other genetic variants that impact disease behavior include an SNP in IRGM (rs4958847), which was significantly associated with frequency of surgery in a study of 66 patients with ileocecal CD, and a negative association was found between ileal disease and TLR1 S602I. ${ }^{76}$ Genetic variants may also impact the response to certain immune therapies; polymorphisms in multidrug resistant $1, \mathrm{TNF}$, and migration inhibitory factor genes have all been associated with sensitivity to corticosteroid, ${ }^{77,78}$ while variants in apoptosis genes have been used to predict the response to infliximab therapy. ${ }^{79}$ The identification of genetic variants could be an important tool in predicting disease behavior and responsiveness of certain patients to specific treatments; however, this may be complicated by the major role that other factors, such as the environment, plays in $\mathrm{CD}$ pathogenesis. It may be worthwhile to examine genetic variants alongside clinical, serological, and microbiological data in order to more accurately predict disease behavior.

\section{Genetic variants in pediatric Crohn's disease}

Phenotypic differences between adult and pediatric onset $C D$ suggest a different genetic predisposition. Pediatric IBD is characterized by extensive intestinal involvement and rapid early progression. ${ }^{80}$ The increased risk of CD among family members with early-onset disease and the stratification of disease by age of onset has been the focus of many studies in the effort to further ascertain the genetic influence of CD.

Genetic susceptibility may play a more important role in the etiology of early-onset IBD than in late-onset IBD, and therefore pediatric-onset IBD patients can be expected to have a higher frequency of gene mutations. De Ridder and colleagues ${ }^{81}$ investigated genetic polymorphism in CARD15 and DLG5 and described more frequent occurrence of polymorphisms, 3020insC, in CARD15 and SNP, rs3792876, in SLC22A4/5 in patients with pediatric-onset
$\mathrm{CD}$ than in patients with adult-onset CD. Polymorphisms 3020 insC in CARD15 and SNP rs2165047 in DLG5 were associated with specific phenotypes such as ileal and perianal disease, respectively. In another pediatric study in the GWAS literature, ${ }^{82}$ a previously unreported susceptibility locus for pediatric-onset IBD at 20q13 and 21q22 was identified, suggesting that TNFRSF6B is the most plausible candidate within the $20 \mathrm{q} 13$ locus, involved in both antigen-presenting cell differentiation and lymphocyte function. Autophagy-associated genes (ATG16L1 and IRGM) were also seen in early-onset $\mathrm{CD}$ cases, further confirming autophagy as an important contributor in the pathogenesis of pediatric CD. ${ }^{83}$

Dubinsky et $\mathrm{al}^{84}$ examined associations between the R381Q variant of the IL-23R gene and CD in a pediatric cohort and reported significant associations using a familybased study. Similarly, Van Limbergen et $\mathrm{al}^{85}$ also reported associations with the same SNP in a Scottish cohort of pediatric $\mathrm{CD}$ using the case-control design. These reports provide strong evidence that the $I L-23 R$ gene is not only associated with adult-onset $\mathrm{CD}$, but similar associations exist for children among most Caucasian populations.

\section{Conclusions and perspectives}

Currently there are more than 100 independent genetic loci contributing to the pathophysiology of CD. While many of these genes are considered risk factors, we are beginning to discover other genes that may help predict disease behavior as well as the response to certain immune therapies. Particularly interesting will be the further investigation of genes associated with pediatric early onset, thus allowing us the capability to identify children at a higher risk of disease and provide a more effective therapeutic approach. The last decade has witnessed a great expansion in our knowledge of the genetic variants in $\mathrm{CD}$ and the identification of many genetic factors that influence the innate immune response. These findings have provided an extensive framework for unraveling the genetic basis of disease susceptibility, clinical predictors of disease behavior, and biological processes of disease. As our understanding becomes more robust, greater insight into the genetic influence in $\mathrm{CD}$ will continue to be critical for the development of future therapeutic strategies.

\section{Disclosure}

The authors report no conflicts of interests in this work.

\section{References}

1. Mathew CG. New links to the pathogenesis of Crohn disease provided by genome-wide association scans. Nat Rev Genet. 2008;9(1): 9-14. 
2. Benchimol EI, Guttmann A, To T, Rabeneck L, Griffiths AM. Changes to surgical and hospitalization rates of pediatric inflammatory bowel disease in Ontario, Canada (1994-2007). Inflamm Bowel Dis. 2011; 17(10):2153-2161.

3. Rioux JD, Xavier RJ, Taylor KD, et al. Genome-wide association study identifies new susceptibility loci for Crohn disease and implicates autophagy in disease pathogenesis. Nat Genet. 2007;39(5): 596-604.

4. Hampe J, Franke A, Rosenstiel P, et al. A genome-wide association scan of nonsynonymous SNPs identifies a susceptibility variant for Crohn disease in ATG16L1. Nat Genet. 2007;39(2):207-211.

5. Parkes M, Barrett JC, Prescott NJ, et al. Sequence variants in the autophagy gene IRGM and multiple other replicating loci contribute to Crohn's disease susceptibility. Nat Genet. 2007;39(7):830-832.

6. Duerr RH, Taylor KD, Brant SR, et al. A genome-wide association study identifies IL23R as an inflammatory bowel disease gene. Science. 2006;314(5804):1461-1463.

7. Tremelling M, Cummings F, Fisher SA, et al. IL23R variation determines susceptibility but not disease phenotype in inflammatory bowel disease. Gastroenterology. 2007;132(5):1657-1664.

8. Jostins L, Ripke S, Weersma RK, et al. Host-microbe interactions have shaped the genetic architecture of inflammatory bowel disease. Nature. 2012;491(7422):119-124

9. Wagner J, Skinner NA, Catto-Smith AG, et al. TLR4, IL10RA, and NOD2 mutation in paediatric Crohn's disease patients: an association with Mycobacterium avium subspecies paratuberculosis and TLR4 and IL10RA expression. Med Microbiol Immunol. Epub March 2, 2013.

10. Hugot JP, Chamaillard M, Zouali H, et al. Association of NOD2 leucine-rich repeat variants with susceptibility to Crohn's disease. Nature. 2001;411(6837):599-603.

11. Weersma RK, Stokkers PC, van Bodegraven AA, et al; Dutch Initiative on Crohn and Colitis (ICC). Molecular prediction of disease risk and severity in a large Dutch Crohn's disease cohort. Gut. 2009;58(3): 388-395.

12. Ogura Y, Bonen DK, Inohara N, et al. A frameshift mutation in NOD2 associated with susceptibility to Crohn's disease. Nature. 2001; 411(6837):603-606.

13. Abreu MT, Taylor KD, Lin YC, et al. Mutations in NOD2 are associated with fibrostenosing disease in patients with Crohn's disease. Gastroenterology. 2002;123(3):679-688.

14. Ahmad T, Armuzzi A, Bunce M, et al. The molecular classification of the clinical manifestations of Crohn's disease. Gastroenterology. 2002;122(4):854-866.

15. Biank V, Broeckel U, Kugathasan S. Pediatric inflammatory bowel disease: clinical and molecular genetics. Inflamm Bowel Dis. 2007; 13(11):1430-1438.

16. Leong RW, Armuzzi A, Ahmad T, et al. NOD2/CARD15 gene polymorphisms and Crohn's disease in the Chinese population. Aliment Pharmacol Ther. 2003;17(12):1465-1470.

17. Sugimura M, Kinouchi Y, Takahashi S, et al. CARD15/NOD2 mutational analysis in Japanese patients with Crohn's disease. Clin Genet. 2003;63(2):160-162.

18. Croucher PJ, Mascheretti S, Hampe J, et al. Haplotype structure and association to Crohn's disease of CARD15 mutations in two ethnically divergent populations. Eur J Hum Genet. 2003;11(1):6-16.

19. Inoue N, Tamura K, Kinouchi Y, et al. Lack of common NOD2 variants in Japanese patients with Crohn's disease. Gastroenterology. 2002; 123(1):86-91

20. Yamazaki K, Takazoe M, Tanaka T, Kazumori T, Nakamura Y. Absence of mutation in the NOD2/CARD15 gene among 483 Japanese patients with Crohn's disease. J Hum Genet. 2002;47(9):469-472.

21. Rivas MA, Beaudoin M, Gardet A, et al. Deep resequencing of GWAS loci identifies independent rare variants associated with inflammatory bowel disease. Nat Genet. 2011;43(11):1066-1073.

22. Stoll M, Corneliussen B, Costello CM, et al. Genetic variation in DLG5 is associated with inflammatory bowel disease. Nat Genet. 2004;36(5): 476-480.
23. Friedrichs F, Brescianini S, Annese V, et al. Evidence of transmission ratio distortion of DLG5 R30Q variant in general and implication of an association with Crohn disease in men. Hum Genet. 2006;119(3): 305-311.

24. Oppmann B, Lesley R, Blom B, et al. Novel p19 protein engages IL-12p40 to form a cytokine, IL-23, with biological activities similar as well as distinct from IL-12. Immunity. 2000;13(5):715-725.

25. Neurath MF, Fuss I, Kelsall BL, Stüber E, Strober W. Antibodies to interleukin 12 abrogate established experimental colitis in mice. $J$ Exp Med. 1995;182(5):1281-1290.

26. Simpson SJ, Shah S, Comiskey M, et al. T cell-mediated pathology in two models of experimental colitis depends predominantly on the interleukin 12/signal transducer and activator of transcription (Stat)-4 pathway, but is not conditional on interferon gamma expression by T cells. J Exp Med. 1998;187(8):1225-1234.

27. Bettelli E, Carrier Y, Gao W, et al. Reciprocal developmental pathways for the generation of pathogenic effector TH17 and regulatory T cells. Nature. 2006;441(7090):235-238.

28. Buonocore S, Ahern PP, Uhlig HH, et al. Innate lymphoid cells drive interleukin-23-dependent innate intestinal pathology. Nature. 2010;464(7293):1371-1375.

29. Aggarwal S, Ghilardi N, Xie MH, de Sauvage FJ, Gurney AL. Interleukin-23 promotes a distinct $\mathrm{CD} 4 \mathrm{~T}$ cell activation state characterized by the production of interleukin-17. J Biol Chem. 2003;278(3): $1910-1914$

30. Strober W, Zhang F, Kitani A, Fuss I, Fichtner-Feigl S. Proinflammatory cytokines underlying the inflammation of Crohn's disease. Curr Opin Gastroenterol. 2010;26(4):310-317.

31. Fuss IJ. Is the Th1/Th2 paradigm of immune regulation applicable to IBD? Inflamm Bowel Dis. 2008;14(Suppl 2):S110-S112.

32. Olsen T, Rismo R, Cui G, Goll R, Christiansen I, Florholmen J. TH1 and TH17 interactions in untreated inflamed mucosa of inflammatory bowel disease, and their potential to mediate the inflammation. Cytokine. 2011;56(3):633-640.

33. Kleinschek MA, Boniface K, Sadekova S, et al. Circulating and gutresident human Th17 cells express CD161 and promote intestinal inflammation. J Exp Med. 2009;206(3):525-534.

34. Rismo R, Olsen T, Cui G, et al. Normalization of mucosal cytokine gene expression levels predicts long-term remission after discontinuation of anti-TNF therapy in Crohn's disease. Scand J Gastroenterol. 2013;48(3):311-319.

35. Choi AM, Ryter SW, Levine B. Autophagy in human health and disease. N Engl J Med. 2013;368(7):651-662.

36. Mizushima N, Yoshimori T, Ohsumi Y. The role of Atg proteins in autophagosome formation. Annu Rev Cell Dev Biol. 2011;27: $107-132$.

37. Mehrpour M, Esclatine A, Beau I, Codogno P. Overview of macroautophagy regulation in mammalian cells. Cell Res. 2010;20(7): 748-762.

38. Alirezaei M, Fox HS, Flynn CT, et al. Elevated ATG5 expression in autoimmune demyelination and multiple sclerosis. Autophagy. 2009;5(2):152-158.

39. Gukovsky I, Gukovskaya AS. Impaired autophagy underlies key pathological responses of acute pancreatitis. Autophagy. 2010;6(3): 428-429.

40. Mareninova OA, Hermann K, French SW, et al. Impaired autophagic flux mediates acinar cell vacuole formation and trypsinogen activation in rodent models of acute pancreatitis. J Clin Invest. 2009;119(11): 3340-3355.

41. Fujitani Y, Kawamori R, Watada H. The role of autophagy in pancreatic beta-cell and diabetes. Autophagy. 2009;5(2):280-282.

42. Ireland JM, Unanue ER. Autophagy in antigen-presenting cells results in presentation of citrullinated peptides to CD4 T cells. J Exp Med. 2011;208(13):2625-2632.

43. Han JW, Zheng HF, Cui Y, et al. Genome-wide association study in a Chinese Han population identifies nine new susceptibility loci for systemic lupus erythematosus. Nat Genet. 2009;41(11):1234-1237. 
44. Gateva V, Sandling JK, Hom G, et al. A large-scale replication study identifies TNIP1, PRDM1, JAZF1, UHRF1BP1 and IL10 as risk loci for systemic lupus erythematosus. Nat Genet. 2009;41(11):1228-1233.

45. International Consortium for Systemic Lupus Erythemoatosus Genetics (SLEGEN), Harley JB, Alarcón-Riquelme ME, et al. Genome-wide association scan in women with systemic lupus erythematosus identifies susceptibility variants in ITGAM, PXK, KIAA1542 and other loci. Nat Genet. 2008;40(2):204-210.

46. Pierdominici M, Vomero M, Barbati C, et al. Role of autophagy in immunity and autoimmunity, with a special focus on systemic lupus erythematosus. FASEB J. 2012;26(4):1400-1412.

47. Chong S, Vickaryous N, Ashe A, et al. Modifiers of epigenetic reprogramming show paternal effects in the mouse. Nat Genet. 2007;39(5): 614-622.

48. Levine B, Kroemer G. Autophagy in the pathogenesis of disease. Cell. 2008;132(1):27-42.

49. Levine B, Mizushima N, Virgin HW. Autophagy in immunity and inflammation. Nature. 2011;469(7330):323-335.

50. Kuballa P, Nolte WM, Castoreno AB, Xavier RJ. Autophagy and the immune system. Annu Rev Immunol. 2012;30:611-646.

51. Travassos LH, Carneiro LA, Ramjeet M, et al. Nod1 and Nod2 direct autophagy by recruiting ATG16L1 to the plasma membrane at the site of bacterial entry. Nat Immunol. 2010;11(1):55-62.

52. Cooney R, Baker J, Brain O, et al. NOD2 stimulation induces autophagy in dendritic cells influencing bacterial handling and antigen presentation. Nat Med. 2010;16(1):90-97.

53. Plantinga TS, Crisan TO, Oosting M, et al. Crohn's disease-associated ATG16L1 polymorphism modulates pro-inflammatory cytokine responses selectively upon activation of NOD2. Gut. 2011;60(9):1229-1235.

54. Sanjuan MA, Dillon CP, Tait SW, et al. Toll-like receptor signalling in macrophages links the autophagy pathway to phagocytosis. Nature. 2007;450(7173):1253-1257.

55. Waltz P, Carchman EH, Young AC, et al. Lipopolysaccaride induces autophagic signaling in macrophages via a TLR4, heme oxygenase-1 dependent pathway. Autophagy. 2011;7(3):315-320.

56. Singh SB, Davis AS, Taylor GA, Deretic V. Human IRGM induces autophagy to eliminate intracellular mycobacteria. Science. 2006;313(5792):1438-1441.

57. Deretic V, Master S, Singh S. Autophagy gives a nod and a wink to the inflammasome and Paneth cells in Crohn's disease. Dev Cell. 2008;15(5):641-642.

58. Gutierrez MG, Master SS, Singh SB, Taylor GA, Colombo MI, Deretic V. Autophagy is a defense mechanism inhibiting BCG and Mycobacterium tuberculosis survival in infected macrophages. Cell. 2004;119(6):753-766.

59. McCarroll SA, Huett A, Kuballa P, et al. Deletion polymorphism upstream of IRGM associated with altered IRGM expression and Crohn's disease. Nat Genet. 2008;40(9):1107-1112.

60. Latiano A, Palmieri O, Cucchiara S, et al. Polymorphism of the IRGM gene might predispose to fistulizing behavior in Crohn's disease. $\mathrm{Am}$ J Gastroenterol. 2009;104(1):110-116.

61. Sehgal R, Berg A, Polinski JI, et al. Mutations in IRGM are associated with more frequent need for surgery in patients with ileocolonic Crohn's disease. Dis Colon Rectum. 2012;55(2):115-121.

62. Brest P, Lapaquette P, Souidi M, et al. A synonymous variant in IRGM alters a binding site for miR-196 and causes deregulation of IRGMdependent xenophagy in Crohn's disease. Nat Genet. 2011;43(3): 242-245.

63. Manning G, Whyte DB, Martinez R, Hunter T, Sudarsanam S. The protein kinase complement of the human genome. Science. 2002;298(5600):1912-1934.

64. Franke A, McGovern DP, Barrett JC, et al. Genome-wide meta-analysis increases to 71 the number of confirmed Crohn's disease susceptibility loci. Nat Genet. 2010;42(12):1118-1125.

65. Umeno J, Asano K, Matsushita T, et al. Meta-analysis of published studies identified eight additional common susceptibility loci for Crohn's disease and ulcerative colitis. Inflamm Bowel Dis. 2011;17(12):2407-2415.
66. Barrett JH, Iles MM, Harland M, et al; GenoMEL Consortium. Genome-wide association study identifies three new melanoma susceptibility loci. Nat Genet. 2011;43(11):1108-1113.

67. Berwick DC, Harvey K. LRRK2 signaling pathways: the key to unlocking neurodegeneration? Trends Cell Biol. 2011;21(5):257-265.

68. Alegre-Abarrategui J, Christian H, Lufino MM, et al. LRRK2 regulates autophagic activity and localizes to specific membrane microdomains in a novel human genomic reporter cellular model. Hum Mol Genet. 2009;18(21):4022-4034.

69. Gómez-Suaga P, Luzón-Toro B, Churamani D, et al. Leucine-rich repeat kinase 2 regulates autophagy through a calcium-dependent pathway involving NAADP. Hum Mol Genet. 2012;21(3):511-525.

70. Mizushima N. The role of the Atg1/ULK1 complex in autophagy regulation. Curr Opin Cell Biol. 2010;22(2):132-139.

71. Henckaerts L, Cleynen I, Brinar M, et al. Genetic variation in the autophagy gene ULK1 and risk of Crohn's disease. Inflamm Bowel Dis. 2011;17(6):1392-1397.

72. Cleynen I, González JR, Figueroa C, et al. Genetic factors conferring an increased susceptibility to develop Crohn's disease also influence disease phenotype: results from the IBDchip European Project. Gut. Epub December 21, 2012.

73. Alvarez-Lobos M, Arostegui JI, Sans M, et al. Crohn's disease patients carrying Nod2/CARD15 gene variants have an increased and early need for first surgery due to stricturing disease and higher rate of surgical recurrence. Ann Surg. 2005;242(5):693-700.

74. Renda MC, Orlando A, Civitavecchia G, et al. The role of CARD15 mutations and smoking in the course of Crohn's disease in a Mediterranean area. Am J Gastroenterol. 2008;103(3):649-655.

75. Prager M, Büttner J, Haas V, et al. The JAK2 variant rs10758669 in Crohn's disease: altering the intestinal barrier as one mechanism of action. Int J Colorectal Dis. 2012;27(5):565-573.

76. Pierik M, Joossens S, Van Steen K, et al. Toll-like receptor-1, -2, and -6 polymorphisms influence disease extension in inflammatory bowel diseases. Inflamm Bowel Dis. 2006;12(1):1-8.

77. Farrell RJ, Kelleher D. Glucocorticoid resistance in inflammatory bowel disease. J Endocrinol. 2003;178(3):339-346.

78. Potocnik U, Ferkolj I, Glavac D, Dean M. Polymorphisms in multidrug resistance 1 (MDR1) gene are associated with refractory Crohn disease and ulcerative colitis. Genes Immun. 2004;5(7):530-539.

79. Cucchiara S, Latiano A, Palmieri O, et al; Italian Society of Pediatric Gastroenterology and Nutrition. Polymorphisms of tumor necrosis factor-alpha but not MDR1 influence response to medical therapy in pediatric-onset inflammatory bowel disease. J Pediatr Gastroenterol Nutr. 2007;44(2):171-179.

80. Van Limbergen J, Russell RK, Drummond HE, et al. Definition of phenotypic characteristics of childhood-onset inflammatory bowel disease. Gastroenterology. 2008;135(4):1114-1122.

81. de Ridder L, Weersma RK, Dijkstra G, et al. Genetic susceptibility has a more important role in pediatric-onset Crohn's disease than in adult-onset Crohn's disease. Inflamm Bowel Dis. 2007;13(9): 1083-1092.

82. Kugathasan S, Baldassano RN, Bradfield JP, et al. Loci on 20q13 and 21 q22 are associated with pediatric-onset inflammatory bowel disease. Nat Genet. 2008;40(10):1211-1215.

83. Peterson N, Guthery S, Denson L, et al. Genetic variants in the autophagy pathway contribute to paediatric Crohn's disease. Gut. 2008; 57(9):1336-1337.

84. Dubinsky MC, Wang D, Picornell Y, et al; Western Regional Research Alliance for Pediatric IBD. IL-23 receptor (IL-23R) gene protects against pediatric Crohn's disease. Inflamm Bowel Dis. 2007;13(5): 511-515.

85. Van Limbergen J, Russell RK, Nimmo ER, et al. IL23R Arg381Gln is associated with childhood onset inflammatory bowel disease in Scotland. Gut. 2007;56(8):1173-1174.

86. Zhou Z, Lin XY, Akolkar PN, et al. Variation at NOD2/CARD15 in familial and sporadic cases of Crohn's disease in the Ashkenazi Jewish population. Am J Gastroenterol. 2002;97(12):3095-3101. 
87. Vavassori P, Borgiani P, Biancone L, et al. CARD15 mutation analysis in an Italian population: Leu1007fsinsC but neither Arg702Trp nor Gly908 Arg mutations are associated with Crohn's disease. Inflamm Bowel Dis. 2004;10(2):116-121.

88. Arnott ID, Nimmo ER, Drummond HE, et al. NOD2/CARD15, TLR4 and CD14 mutations in Scottish and Irish Crohn's disease patients: evidence for genetic heterogeneity within Europe? Genes Immun. 2004;5(5):417-425.

89. Gazouli M, Mantzaris G, Kotsinas A, et al. Association between polymorphisms in the Toll-like receptor 4, CD14, and CARD15/NOD2 and inflammatory bowel disease in the Greek population. World $J$ Gastroenterol. 2005;11(5):681-685.

90. Baldassano RN, Bradfield JP, Monos DS, et al. Association of the T300A non-synonymous variant of the ATG16L1 gene with susceptibility to paediatric Crohn's disease. Gut. 2007;56(8):1171-1173.

91. Prescott NJ, Dominy KM, Kubo M, et al. Independent and populationspecific association of risk variants at the IRGM locus with Crohn's disease. Hum Mol Genet. 2010;19(9):1828-1839.

92. Rioux JD, Daly MJ, Silverberg MS, et al. Genetic variation in the $5 \mathrm{q} 31$ cytokine gene cluster confers susceptibility to Crohn disease. Nat Genet. 2001;29(2):223-228.

93. Silverberg MS, Duerr RH, Brant SR, et al; NIDDK IBD Genetics Consortium. Refined genomic localization and ethnic differences observed for the IBD5 association with Crohn's disease. Eur J Hum Genet. 2007;15(3):328-335.

94. Tomer G, Wetzler G, Keddache M, Denson LA. Polymorphisms in the IBD5 locus are associated with Crohn disease in pediatric Ashkenazi Jewish patients. J Pediatr Gastroenterol Nutr. 2009;48(5):531-537.

95. Diaz-Gallo LM, Medrano LM, Gómez-García M, et al. Analysis of the influence of two CD24 genetic variants in Crohn's disease and ulcerative colitis. Hum Immunol. 2011;72(10):969-972.

96. Barrett JC, Hansoul S, Nicolae DL, et al. Genome-wide association defines more than 30 distinct susceptibility loci for Crohn's disease. Nat Genet. 2008;40(8):955-962.

97. Zhu H, Li YR. Oxidative stress and redox signaling mechanisms of inflammatory bowel disease: updated experimental and clinical evidence. Exp Biol Med (Maywood). 2012;237(5):474-480.
98. Atan D, Heissigerova J, Kuffová L, et al. Tumor necrosis factor polymorphisms associated with tumor necrosis factor production influence the risk of idiopathic intermediate uveitis. Mol Vis. 2013;19: $184-195$.

99. Aldhous MC, Nimmo ER, Satsangi J. NOD2/CARD15 and the Paneth cell: another piece in the genetic jigsaw of inflammatory bowel disease. Gut. 2003;52(11):1533-1535.

100. Iwanaga Y, Davey MP, Martin TM, et al. Cloning, sequencing and expression analysis of the mouse NOD2/CARD15 gene. Inflamm Res. 2003;52(6):272-276.

101. Rock FL, Hardiman G, Timans JC, Kastelein RA, Bazan JF. A family of human receptors structurally related to Drosophila Toll. Proc Natl Acad Sci USA. 1998;95(2):588-593.

102. Parham C, Chirica M, Timans J, et al. A receptor for the heterodimeric cytokine IL-23 is composed of IL-12Rbeta1 and a novel cytokine receptor subunit, IL-23R. J Immunol. 2002;168(11):5699-5708.

103. Gründemann D, Harlfinger S, Golz S, et al. Discovery of the ergothioneine transporter. Proc Natl Acad Sci US A. 2005;102(14): 5256-5261.

104. Zheng H, Ji C, Li J, et al. Cloning and analysis of human Apg16L. DNA Seq. 2004;15(4):303-305.

105. Bekpen C, Xavier RJ, Eichler EE. Human IRGM gene "to be or not to be". Semin Immunopathol. 2010;32(4):437-444.

106. Friedrichs F, Stoll M. Role of discs large homolog 5. World $J$ Gastroenterol. 2006;12(23):3651-3656.

107. Orenstein SJ, Kuo SH, Tasset I, et al. Interplay of LRRK2 with chaperone-mediated autophagy. Nat Neurosci. 2013;16(4):394-406.

108. Vang T, Miletic AV, Bottini N, Mustelin T. Protein tyrosine phosphatase PTPN22 in human autoimmunity. Autoimmunity. 2007;40(6): 453-461.

109. Liu Y, Wei SH, Ho AS, de Waal Malefyt R, Moore KW. Expression cloning and characterization of a human IL-10 receptor. J Immunol. 1994;152(4):1821-1829.

110. Locksley RM, Killeen N, Lenardo MJ. The TNF and TNF receptor superfamilies: integrating mammalian biology. Cell. 2001;104(4): 487-501.
The Application of Clinical Genetics

\section{Publish your work in this journal}

The Application of Clinical Genetics is an international, peer-reviewed open access journal that welcomes laboratory and clinical findings in the field of human genetics. Specific topics include: Population genetics; Functional genetics; Natural history of genetic disease; Management of genetic disease; Mechanisms of genetic disease; Counseling and ethical

\section{Dovepress}

issues; Animal models; Pharmacogenetics; Prenatal diagnosis; Dysmorphology. The manuscript management system is completely online and includes a very quick and fair peer-review system, which is all easy to use. Visit http://www.dovepress.com/testimonials.php to read real quotes from published authors. 